\title{
Dynamic Changes in Striatal mGluR1 But Not mGluR5 during Pathological Progression of Parkinson's Disease in Human Alpha-Synuclein A53T Transgenic Rats: A Multi-PET Imaging Study
}

\author{
Tomoteru Yamasaki, ${ }^{1}$ Masayuki Fujinaga, ${ }^{1}$ Kazunori Kawamura, ${ }^{1}$ Kenji Furutsuka, ${ }^{1,2}$ Nobuki Nengaki, ${ }^{1,2}$ \\ Yoko Shimoda, ${ }^{1}$ Satoshi Shiomi, ${ }^{1,3}$ Makoto Takei, ${ }^{1}$ Hiroki Hashimoto, ${ }^{1}$ Joji Yui, ${ }^{1}{ }^{\circ}$ Hidekatsu Wakizaka, ${ }^{1}$ Akiko Hatori, ${ }^{1}$ \\ Lin Xie, ${ }^{1}$ Katsushi Kumata, ${ }^{1}$ and Ming-Rong Zhang ${ }^{1}$ \\ ${ }^{1}$ Molecular Imaging Center, National Institute of Radiological Sciences, Chiba 263-8555, Japan, ${ }^{2}$ SHI Accelerator Service, Tokyo 141-8686, Japan, and \\ ${ }^{3}$ Tokyo Nuclear Services, Tokyo 110-0016, Japan
}

Parkinson's disease (PD) is a prevalent degenerative disorder affecting the CNS that is primarily characterized by resting tremor and movement deficits. Group I metabotropic glutamate receptor subtypes 1 and 5 (mGluR1 and mGluR5, respectively) are important targets for investigation in several CNS disorders. In the present study, we investigated the in vivo roles of mGluR1 and mGluR5 in chronic PD pathology by performing longitudinal positron emission tomography (PET) imaging in A53T transgenic (A53T-Tg) rats expressing an abnormal human $\alpha$-synuclein (ASN) gene. A53T- $\mathrm{Tg}$ rats showed a dramatic decline in general motor activities with age, along with abnormal ASN aggregation and striatal neuron degeneration. In longitudinal PET imaging, striatal nondisplaceable binding potential $\left(\mathrm{BP}_{\mathrm{ND}}\right)$ values for [ $\left.{ }^{11} \mathrm{C}\right] \mathrm{ITDM}\left(\mathrm{N}\right.$-[4-[6-(isopropylamino) pyrimidin-4-yl]-1,3-thiazol-2-yl]- $N$-methyl-4- $\left[{ }^{11} \mathrm{C}\right]$ methylbenzamide), a selective PET ligand for mGluR1, temporarily increased before PD symptom onset and dramatically decreased afterward with age. However, striatal $\mathrm{BP}_{\mathrm{ND}}$ values for $(E)-\left[{ }^{11} \mathrm{C}\right] \mathrm{ABP} 688$ [3-(6-methylpyridin-2-ylethynyl)-cyclohex-2-enone-(E)-O- $\left[{ }^{11} \mathrm{C}\right]$ methyloxime], a specific PET ligand for mGluR5, remained constant during experimental terms. The dynamic changes in striatal mGluR1 $\mathrm{BP}_{\mathrm{ND}}$ values also showed a high correlation in pathological decreases in general motor activities. Furthermore, declines in $m G l u R 1 \mathrm{BP}_{\mathrm{ND}}$ values were correlated with decreases in $\mathrm{BP}_{\mathrm{ND}}$ values for $\left[{ }^{18} \mathrm{~F}\right] \mathrm{FE}$-PE2I $\left[(E)-N\right.$-(3-iodoprop-2E-enyl)-2 $\beta$-carbo- $\left[{ }^{18} \mathrm{~F}\right]$ fluoroethoxy-3 $\beta$-(4-methylphenyl) nortropane], a specific PET ligand for the dopamine transporter, a biomarker for dopaminergic neurons. In conclusion, our results have demonstrated for the first time that dynamic changes occur in mGluR1, but not mGluR5, that accompany pathological progression in a PD animal model.

Key words: nondisplaceable binding potential; dopamine transporter; mGluR1; mGluR5; Parkinson’s disease; PET

\section{Significance Statement}

Synaptic signaling by glutamate, the principal excitatory neurotransmitter in the brain, is modulated by group I metabotropic glutamate receptors, including the mGluR1 and mGluR5 subtypes. In the brain, mGluR1 and mGluR5 have distinct functional roles and regional distributions. Their roles in brain pathology, however, are not well characterized. Using longitudinal PET imaging in a chronic rat model of PD, we demonstrated that expression of mGluR1, but not mGluR5, dynamically changed in the striatum accompanying pathological PD progression. These findings imply that monitoring mGluR1 in vivo may provide beneficial information to further understand central nervous system disorders.

\section{Introduction}

Parkinson's disease (PD) is the second most common chronic neurodegenerative disorder, following Alzheimer disease (AD), and is characterized by akinesia, tremor, rigidity, and poor balance. PD is believed to be caused by a combination of environmental and genetic factors leading to structural changes in the 
protein $\alpha$-synuclein (ASN). In neurons, alterations in ASN structure can lead to protein aggregation, forming soluble oligomers and insoluble filaments known as Lewy bodies, which are a hallmark of PD pathology. Aggregation of abnormal ASN can affect many factors in neurodegenerative disorders, such as oxidative stress, neuroinflammation, and synaptic transmissions (Roberts and Brown, 2015).

Glutamate is the primary neurotransmitter involved in excitatory neurotransmission. Among the glutamate receptor family, metabotropic glutamate receptors are G-protein-coupled receptors comprising eight subtypes (mGluR1-mGluR8). These subtypes are divided into three groups (groups I-III), based on differences in the G-protein $\alpha$ subunit and subsequent transduction pathways ( $\mathrm{Na}-$ kanishi et al., 1998). The receptor subtypes mGluR1 and mGluR5 are members of group I, and activate the $\mathrm{G}_{\mathrm{q}}$-protein. This process initiates the phosphatidylinositol-signaling pathway, which leads to intracellular calcium release and protein kinase $\mathrm{C}$ activation (Aramori and Nakanishi, 1992; Francesconi and Duvoisin, 1998; Ferraguti et al., 2008). Thus, mGluR1 and mGluR5 can trigger phosphorylation-signaling cascades and modulate gated ion channel activity via intracellular calcium release. Although mGluR1 and mGluR5 exhibit a high degree of homology, each has a distinct regional distribution and expression pattern in the brain (Abe et al., 1992; Fotuhi et al., 1993). At present, the respective roles of mGluR1 and mGluR5 in CNS disorders are not well characterized.

A number of reports have demonstrated that mGluR1 and mGluR5 modulators provided neuroprotection in CNS disorders such as stroke (Bao et al., 2001; Kohara et al., 2008), Huntington's disease (Schiefer et al., 2004), AD (Ulus and Wurtman, 1997), epilepsy (Löscher et al., 2006; Tang et al., 2007), and PD (Dekundy et al., 2006; Vernon et al., 2008; De Leonibus et al., 2009; Rylander et al., 2010). Moreover, in acute PD models using 6-hydroxy dopamine (6-OHDA) and 1-methyl-4-phenyl1,2,3,6-tetrahydropyridine, mGluR1 or mGluR5 antagonist administration protected against dopaminergic neuronal loss in the substantia nigra (Aguirre et al., 2001; Vernon et al., 2007). Additionally, in a 6-OHDA-treated nonhuman primate acute PD model, mGluR5 expression was elevated in the striatum, whereas mGluR1 expression was decreased in the globus pallidus and substantia nigra (Kaneda et al., 2005; Samadi et al., 2008; Sanchez-Pernaute et al., 2008). These findings suggest that alterations in group I mGluR expression are associated with the onset of PD. Thus, group I mGluRs may be potentially useful biomarkers to characterize PD-related brain pathology.

Positron emission tomography (PET) is frequently used to monitor in vivo brain activity, and allows for noninvasive assessment of longitudinal changes in target molecules. In this study, we monitored longitudinal changes in striatal group I mGluR expression among chronic PD model rats with abnormal ASN aggregation using selective radioligands and PET imaging.

The authors declare no competing financial interests.

Correspondence should be addressed to Dr. Tomoteru Yamasaki, Molecular Probe Program, Molecular Imaging Center, National Institute of Radiological Sciences, 4-9-1 Anagawa, Inage-ku, Chiba 263-8555, Japan. E-mail: yamato@nirs.go.jp.

DOI:10.1523/JNEUROSCI.2289-15.2016

Copyright $\odot 2016$ the authors $\quad 0270-6474 / 16 / 360376-10 \$ 15.00 / 0$ figure 1. Chemical structures of PET ligands used in this study.

\section{Materials and Methods}

Animals. Female Sprague Dawley transgenic rats expressing human mutant A53T ASN (A53T-Tg; $n=12)$ and noncarrier rats $(n=6)$ were purchased from Taconic Biosciences. Animals were kept in a temperature-controlled environment with a $12 \mathrm{~h}$ light/dark cycle and were given a standard diet (Funabashi Farm). All animal experiments were performed according to the recommendations specified by the Committee for the Care and Use of Laboratory Animals of the National Institute of Radiological Sciences.

Production of radioligands. Three PET ligands (Fig. 1) were synthesized in our laboratory and used to monitor group I metabotropic glutamate receptors (mGluR1 and mGluR5) and dopaminergic neurons. Imaging of mGluR 1 was performed using the mGluR1-selective PET ligand $N$-[4-[6-(isopropylamino) pyrimidin-4-yl]-1,3-thiazol2-yl]-N-methyl-4-[ $\left.{ }^{11} \mathrm{C}\right]$ methylbenzamide ([ $\left.{ }^{11} \mathrm{C}\right]$ ITDM; Fujinaga et al., 2012). At the end of synthesis (EOS), $\left[{ }^{11} \mathrm{C}\right]$ ITDM had $>99 \%$ radiochemical purity and $56-144 \mathrm{GBq} / \mu \mathrm{mol}$ specific activity (SA).

For mGluR5 imaging, we used the mGluR5-selective PET ligand 3-(6methylpyridin-2-ylethynyl)-cyclohex-2-enone- $(E)-O-\left[{ }^{11} \mathrm{C}\right]$ methyloxime $\left[(E)-\left[{ }^{11} \mathrm{C}\right] \mathrm{ABP} 688\right.$; Kawamura et al., 2014], yielding $>99 \%$ radiochemical purity and $91-304 \mathrm{GBq} / \mu \mathrm{mol} \mathrm{SA}$ at EOS.

To visualize dopaminergic neurons, the dopamine transporter (DAT)-selective PET ligand (E)- $N$-(3-iodoprop-2 E-enyl)-2 $\beta$-carbo$\left[{ }^{18} \mathrm{~F}\right]$ fluoroethoxy-3 $\beta$-(4-methylphenyl) nortropane ([ $\left.\left.{ }^{18} \mathrm{~F}\right] \mathrm{FE}-\mathrm{PE} 2 \mathrm{I}\right)$ was used (Schou et al., 2009). At EOS, $\left[{ }^{18} \mathrm{~F}\right] \mathrm{FE}-\mathrm{PE} 2 \mathrm{I}$ had $>99 \%$ radiochemical purity and $28-279 \mathrm{GBq} / \mu \mathrm{mol}$ SA.

Open-field test. The open field area $(60 \mathrm{~cm}$ height by $60 \mathrm{~cm}$ width by 45 $\mathrm{cm}$ depth) was made from acrylic sheets and was divided into 16 equalarea squares. The open-field test (OFT) was used to evaluate exploratory activity in the rats. Each rat was placed in the center of the arena and was scored according to the numbers of squares the four paws crossed (locomotion). Rats were also scored for rearing, which was defined as the number of times that each rat had both front paws off the floor for a $5 \mathrm{~min}$ period, after 1 min of habituation. Before introducing each animal, any odors left in the arena by previous animals were eliminated using $70 \%$ ethanol.

Immunohistochemistry. Noncarrier and A53T-Tg rats (aged 16 months; $n=3$ per group) were anesthetized using $1.5 \%(\mathrm{v} / \mathrm{v})$ isoflurane and killed by cervical dislocation. Their brains were quickly removed and frozen. Brain sections (10 $\mu \mathrm{m}$ thick) were prepared from frozen rat brains using a cryostat (HM560; Carl Zeiss) and mounted on slide glass (Matsunami). The slides were dried and then fixed in $4 \%$ paraformaldehyde for $15 \mathrm{~min}$ at room temperature. After washing with PBS, the slides were dipped in saline containing $1 \% \mathrm{H}_{2} \mathrm{O}_{2}$ for $10 \mathrm{~min}$. The slides were then immunostained with mouse polyclonal antibodies against human ASN proteins (Santa Cruz Biotechnology) and rabbit polyclonal antibodies against tyrosine hydroxylase (TH; Santa Cruz Biotechnology) using avidin-biotin complex immunostaining kits (ImmunoCruz; Santa Cruz Biotechnology) and examined using an all-in-one microscope and digital camera (Olympus).

PET procedure. After conducting the OFT, four to six rats in each group were selected for PET experiments based on general motor activity scores. Similar rats based on scoring criteria were used in the scheduled PET experiments (as shown in Fig. 2).

Each rat was anesthetized using $1.5 \%(\mathrm{v} / \mathrm{v})$ isoflurane, and a 24-gauge intravenous catheter (Terumo Medical) was inserted into the tail vein. 
A

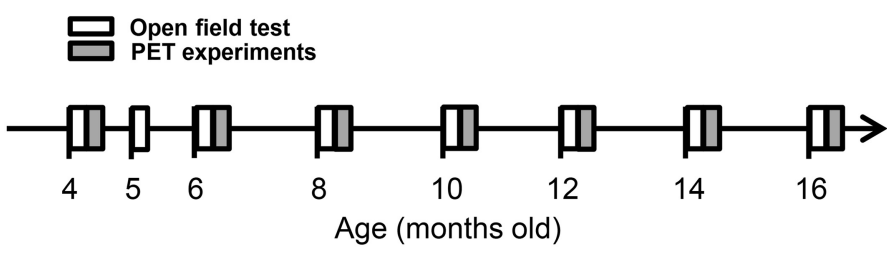

B

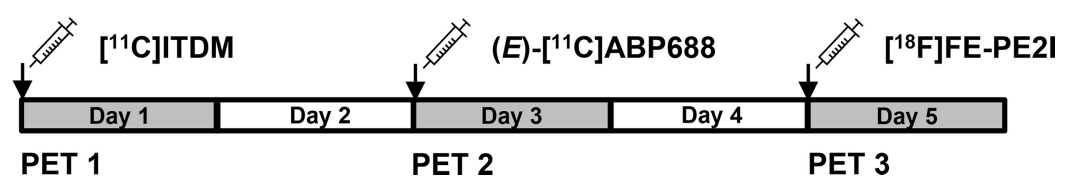

Figure 2. Experimental schedule for open-field testing and PET scans. $\boldsymbol{A}$, Experimental time points in noncarrier and $A 53 T-T g$ rats. $\boldsymbol{B}$, PET scan schedule for a given rat over the course of a week.

Rats were subsequently maintained under anesthesia and secured in a custom-designed chamber placed in the center of a small-animal PET scanner (Inveon; Siemens).

After target position adjustment for brain scanning, the dynamic emission scans (in three-dimensional list mode) were performed as follows: for $\left[{ }^{11} \mathrm{C}\right] \mathrm{ITDM}$, emission scans were performed for $90 \mathrm{~min}(12$ frames for $10 \mathrm{~s}$ each, 3 frames for $20 \mathrm{~s}$ each, 3 frames for $30 \mathrm{~s}$ each, 3 frames for $1 \mathrm{~min}$ each, 3 frames for $2.5 \mathrm{~min}$ each, and 15 frames for $5 \mathrm{~min}$ each); for $(E)-\left[{ }^{11} \mathrm{C}\right] \mathrm{ABP} 688$ and $\left[{ }^{18} \mathrm{~F}\right] \mathrm{FE}-\mathrm{PE} 2 \mathrm{I}$, emission scans were each acquired for $60 \mathrm{~min}$ ( 12 frames for $10 \mathrm{~s}$ each, 3 frames for $20 \mathrm{~s}$ each, 3 frames for $30 \mathrm{~s}$ each, 3 frames for $1 \mathrm{~min}$ each, 3 frames for $2.5 \mathrm{~min}$ each, and 9 frames for $5 \mathrm{~min}$ each). After a transmission scan for attenuation correction using a ${ }^{57} \mathrm{Co}$ source for $803 \mathrm{~s}$, $\left[{ }^{11} \mathrm{C}\right] \mathrm{ITDM}$ (48-67 MBq, 0.2-0.9 $\mathrm{nmol}),\left(\right.$ E)- $\left[{ }^{11} \mathrm{C}\right] \mathrm{ABP} 688$ (40-54 MBq, $\left.0.1-0.6 \mathrm{nmol}\right)$, or $\left[{ }^{18} \mathrm{~F}\right] \mathrm{FE}-\mathrm{PE} 2 \mathrm{I}$ (11-16 MBq, $0.1-1.2 \mathrm{nmol}$ ) was injected via tail vein catheter. Rat body temperatures were maintained at $37^{\circ} \mathrm{C}$ using a heated $\left(40^{\circ} \mathrm{C}\right)$ water circulation system (T/Pump TP401; Gaymar Industries) during the PET scan. After PET experiments, rats were allowed to recover from anesthesia and were taken back to the animal breeding facility.

Data analysis. Acquired PET dynamic images with a $0.6 \mathrm{~mm}$ slice thickness were reconstructed by filtered-back projection using a Hanning's filter, with a Nyquist cutoff of 0.5 cycles per pixel. Images were then summed using analysis software (ASIPro VM; Siemens). For kinetic analysis, the time-activity curve (TAC) for each radioligand was acquired from the volumes of interest, which were manually mapped onto the striatum and cerebellum (for each radioligand), as well as the hippocampus, cingulate cortex, thalamus, and pons (for $\left[{ }^{11} \mathrm{C}\right] \mathrm{ITDM}$ ) using the rat brain magnetic resonance imaging (MRI) template described previously (Yui et al., 2011). The radioactivity was decay corrected to the injection time and is expressed as the standardized uptake value (SUV), which was normalized to the injected radioactivity and body weight. The SUV was calculated according to the following formula: $\mathrm{SUV}=$ (radioactivity per milliliter tissue/injected radioactivity) $\times$ gram body weight. To obtain the nondisplaceable binding potential $\left(\mathrm{BP}_{\mathrm{ND}}\right)$ for each radioligand, kinetic analyses were performed using reference tissue models by the PMOD software (version 3.4; PMOD Technology). For $\left[{ }^{11} \mathrm{C}\right] \mathrm{ITDM}$, the Logan reference method was chosen for the analysis model, with a $t^{*}=15$ min (Logan et al., 1996), using TACs obtained from the pons as a reference region (Yamasaki et al., 2014). Briefly, selection of $t^{\star}$ was based on visual inspection of the residual plots. A predetermined average of $k_{2}{ }^{\prime}$ was acquired from the simplified reference tissue model (SRTM; Lammertsma and Hume, 1996). For (E)-[ $\left[{ }^{11} \mathrm{C}\right] \mathrm{ABP} 688$ and $\left[{ }^{18} \mathrm{~F}\right]$ FE-PE2I, kinetic analyses were performed according to the SRTM using TACs obtained from the cerebellum as a reference tissue (Elmenhorst et al., 2010; Sasaki et al., 2012). Respective parametric images were scaled according to the $\mathrm{BP}_{\mathrm{ND}}$ and reconstructed using PMOD software and the TACs acquired from reference regions.

In vitro autoradiography. The frozen brains (aged 16 months; $n=3$ per group) were cut into $20-\mu \mathrm{m}$-thick sections using a cryostat (HM560; Carl Zeiss), and the slices were mounted on to glass slides (Matsunami
Glass). The brain sections were preincubated for $20 \mathrm{~min}$ in $50 \mathrm{~mm}$ Tris- $\mathrm{HCl}$ buffer, $\mathrm{pH}$ 7.4, containing $1.2 \mathrm{~mm} \mathrm{MgCl}_{2}$ and $2 \mathrm{mM} \mathrm{CaCl}_{2}$ at room temperature. The sections were then incubated for $30 \mathrm{~min}$ at room temperature in fresh buffer containing $\left[{ }^{11} \mathrm{C}\right]$ ITDM $(18 \mathrm{MBq}$, $1.0 \mathrm{nM}),(E)-\left[{ }^{11} \mathrm{C}\right] \mathrm{ABP} 688$ (6 MBq, $\left.0.4 \mathrm{nM}\right)$, or $\left[{ }^{18} \mathrm{~F}\right] \mathrm{FE}-\mathrm{PE} 2 \mathrm{I}(0.7 \mathrm{MBq}, 16.5 \mathrm{pM})$. After incubation, the brain sections were washed $(3 \times 3$ min) with cold buffer, dipped in cold distilled water, and dried in air. They were placed in contact with imaging plates (BAS-MS2025/Fujifilm). Autoradiograms were acquired using a Bio-Imaging Analyzer System (BAS5000/Fujifilm). Regions of interest (ROIs) in autoradiograms were manually drawn in the striatum. The degree of ligand binding (femtomoles per square millimeter) was calibrated using the MultiGauge analysis software, version 2.3 (Fujifilm).

Statistics. All data are expressed as means \pm SEs. Differences between the noncarrier and A53T-Tg groups were calculated using the Student's $t$ test or two-way ANOVA with repeated measures. Post hoc analyses with Bonferroni method were applied. Statistical significance was determined at a $95 \%(p<0.05)$ confidence level and is denoted with asterisks in the figures.

Correlation coefficients $(r)$ for scatter plots were determined as follows: $r>0.7$, a strong positive linear relationship; $0.7>r>0.4$, a moderate positive relationship; $0.4>r>0.2$, a weak positive linear relationship; $r<0.2$, no linear relationship.

All statistic data were analyzed using GraphPad Prism 5 software.

\section{Results}

General motor activity in noncarrier and $\mathrm{A53T}-\mathrm{Tg}$ rats

Age-associated changes in locomotion and rearing scores of noncarrier and $A 53 T-T g$ rats are shown in Figure 3. Locomotion and rearing scores tended to increase in 4- to 5-month-old $\mathrm{A53T}-\mathrm{Tg}$ rats and then dramatically decreased at older ages. Although a weak correlation $(r=0.319)$ between weight gain and locomotion was observed, significant difference between noncarrier $(n=$ $6)$ and $A 53 T-T g(n=12)$ rats was found in locomotion scores $(p=0.012)$. Locomotion and rearing scores in noncarrier rats also continually decreased with age during the present experimental period. Details of motor activity scores in noncarrier and A53T- $T g$ rats are shown in Table 1.

\section{Immunohistochemistry}

Representative images of brain sections stained by immunohistochemistry from noncarrier and $A 53 \mathrm{~T}-\mathrm{Tg}$ rats at 16 months are shown in Figure 4. Human ASN immunoreactivities were highly prominent in the striatum of $A 53 \mathrm{~T}-\mathrm{Tg}$ rats; partial signal aggregations were also detected (Fig. $4 B$ ). Additionally, striatal synaptic gaps in $A 53 \mathrm{~T}-\mathrm{Tg}$ rats were expanded compared with those of noncarrier rats, indicating that dopaminergic neuronal degeneration had occurred. High immunoreactivity for TH was observed in the substantia nigra of noncarrier rats. In contrast, immunoreactivity for $\mathrm{TH}$ in $\mathrm{A53} \mathrm{T}-\mathrm{Tg}$ rats was low, which also supported degeneration of dopaminergic neurons in $A 53 \mathrm{~T}-\mathrm{Tg}$ rats aged 16 months (Fig. 4D).

\section{Longitudinal PET imaging for group I mGluRs and DAT in the striatum}

Parametric PET images obtained using the radioligands $\left[{ }^{11} \mathrm{C}\right] \mathrm{ITDM},(E)-\left[{ }^{11} \mathrm{C}\right] \mathrm{ABP} 688$, and $\left[{ }^{18} \mathrm{~F}\right] \mathrm{FE}-\mathrm{PE} 2 \mathrm{I}$ in noncarrier and $A 53 T-T g$ rats at different ages $(4,8,12$, and 16 months) are shown in Figure 5. In 4-month-old $A 53 T-T g$ rats, $\mathrm{BP}_{\mathrm{ND}}$-scaled 
A

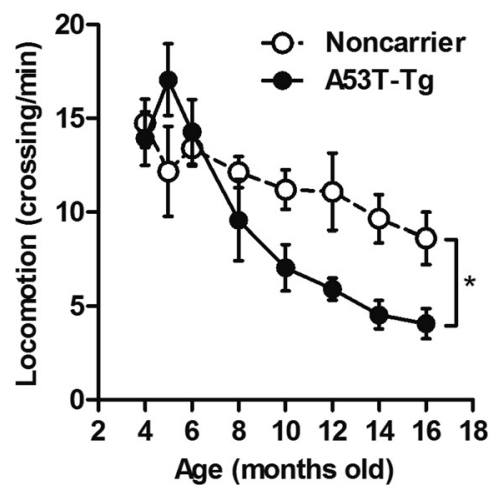

B

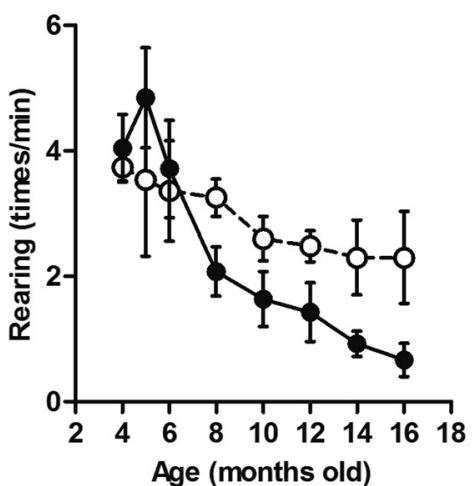

C

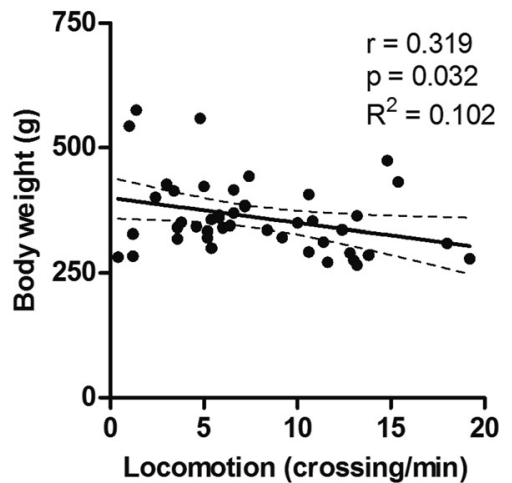

Figure 3. General motor activities in noncarrier and $A 53$ T-Tg rats. $\boldsymbol{A}, \boldsymbol{B}$, Locomotion (number of square crossings per min; $\boldsymbol{A}$ ) and rearing (number of times per min; $\boldsymbol{B}$ ) scores in 4- to 16 -month-old noncarrier ( $n=6$; open circles) and A53T- $\mathrm{Tg}$ ( $n=12$; filled circles) rats. C, Correlation between weight gain and locomotion in animals for PET experiments. ${ }^{*} p<0.05$ (two-way AN0VA). Correlation coefficients $(r), p$ values, and $R^{2}$ values are shown adjacent to the scatter plot.

Table 1. Data for general motor activities of noncarrier and A53T-Tg rats (mean $\pm \mathrm{SE}$ )

\begin{tabular}{|c|c|c|c|c|c|c|c|c|}
\hline & \multicolumn{8}{|l|}{ Age (months) } \\
\hline & 4 & 5 & 6 & 8 & 10 & 12 & 14 & 16 \\
\hline \multicolumn{9}{|l|}{ Noncarrier $(n=6)$} \\
\hline Weight (g) & $283 \pm 11.6$ & $293 \pm 8.5$ & $304 \pm 15.2$ & $318 \pm 12.9$ & $343 \pm 15.2$ & $368 \pm 12.4$ & $360 \pm 11.6$ & $387 \pm 14.6$ \\
\hline Locomotion (crossing/min) & $14.7 \pm 1.30$ & $12.2 \pm 2.41$ & $13.4 \pm 0.95$ & $12.1 \pm 0.83$ & $11.2 \pm 1.06$ & $11.1 \pm 2.05$ & $9.64 \pm 1.28$ & $8.6 \pm 1.38$ \\
\hline Rearing (times/min) & $3.73 \pm 0.22$ & $3.53 \pm 1.21$ & $3.36 \pm 0.80$ & $3.25 \pm 0.30$ & $2.6 \pm 0.35$ & $2.48 \pm 0.25$ & $2.3 \pm 0.59$ & $2.3 \pm 0.73$ \\
\hline \multicolumn{9}{|l|}{$A 53 \mathrm{~T}-\mathrm{Tg}(n=12)$} \\
\hline Weight (g) & $294 \pm 9.8$ & $311 \pm 13.8$ & $337 \pm 10.2$ & $354 \pm 13.7$ & $354 \pm 12.8$ & $415 \pm 31.5$ & $409 \pm 36.7$ & $447 \pm 28.6$ \\
\hline Locomotion (crossing/min) & $13.9 \pm 1.43$ & $17.1 \pm 1.92$ & $14.3 \pm 1.73$ & $8.05 \pm 1.45$ & $7.04 \pm 1.24$ & $5.9 \pm 0.58$ & $4.53 \pm 0.76$ & $4.07 \pm 0.82$ \\
\hline Rearing (times/min) & $4.04 \pm 0.54$ & $4.84 \pm 0.80$ & $3.71 \pm 0.78$ & $2.08 \pm 0.39$ & $1.64 \pm 0.44$ & $1.43 \pm 0.47$ & $0.93 \pm 0.20$ & $0.67 \pm 0.27$ \\
\hline
\end{tabular}

$\left[{ }^{11} \mathrm{C}\right]$ ITDM signals in the striatum were higher than those in noncarrier rats, indicating elevated levels of mGluR1; dramatic signal decreases were subsequently detected at 8 to 16 months in $A 53 T-T g$ rats. However, among noncarrier rats, striatal $\left[{ }^{11} \mathrm{C}\right] \mathrm{ITDM}$ $\mathrm{BP}_{\mathrm{ND}}$ signals only showed a slight decline with age (Fig. $5 A$ ). No differences were detected in $(E)-\left[{ }^{11} \mathrm{C}\right] \mathrm{ABP} 688 \mathrm{BP}_{\mathrm{ND}}$-scaled signals between noncarrier and $A 53 T-T g$ rats, indicating mGluR5 exhibited similar levels between groups; additionally, no signal changes occurred with age (Fig. 5B). We used $\left[{ }^{18} \mathrm{~F}\right]$ FE-PE2I to detect DAT, a known biomarker for dopaminergic neurons. In A53T- $T g$ rats, $\mathrm{BP}_{\mathrm{ND}}$-scaled striatal $\left[{ }^{18} \mathrm{~F}\right] \mathrm{FE}-$ PE2I signals showed age-dependent decreases. Striatal signal area sizes in $A 53 T-T g$ rats also diminished with age. However, $\mathrm{BP}_{\mathrm{ND}}$-scaled $\left[{ }^{18} \mathrm{~F}\right] \mathrm{FE}-\mathrm{PE} 2 \mathrm{I}$ signals in noncarrier rats maintained constant values during the experimental term, with unchanging striatal area sizes (Fig. 5C).

The longitudinal striatal $\mathrm{BP}_{\mathrm{ND}}$ values for $\left[{ }^{11} \mathrm{C}\right] \operatorname{ITDM},(E)-\left[{ }^{11} \mathrm{C}\right] \mathrm{ABP} 688$, and $\left[{ }^{18} \mathrm{~F}\right] \mathrm{FE}-\mathrm{PE} 2 \mathrm{I}$ binding are shown in Figure 6. In noncarrier rats, $\left[{ }^{11} \mathrm{C}\right] \mathrm{ITDM}$ $\mathrm{BP}_{\mathrm{ND}}$ values were maintained at $\sim 2.8$ between 4 and 8 months, and then showed a moderate decrease with age. The final $\mathrm{BP}_{\mathrm{ND}}$ value (at 16 months) in the noncarrier rat group was 2.3 , indicating a $15 \%$ reduction from values at 4 months. In $A 53 T-T g$ rats, the initial $\left[{ }^{11} \mathrm{C}\right] \mathrm{ITDM} \mathrm{BP}_{\mathrm{ND}}$ value at 4
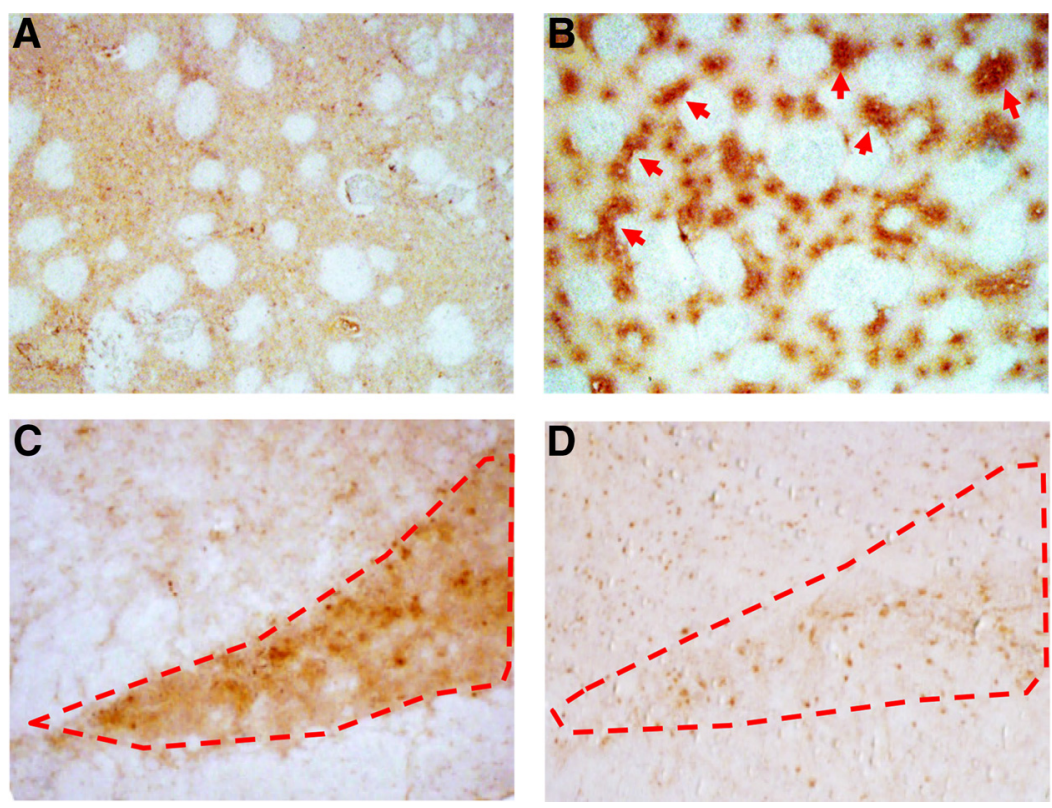

Figure 4. $\boldsymbol{A}-\boldsymbol{D}$, Representative immunohistochemical images for human ASN and TH on brain sections of noncarrier (16month-old; $\boldsymbol{A}, \boldsymbol{C})$ and $A 53 \mathrm{~T}$ - $\mathrm{g}$ (16-month-old; $\boldsymbol{B}, \boldsymbol{D})$ rats. Brain sections containing the caudate/putamen $(\boldsymbol{A}, \boldsymbol{B})$ and substantia nigra $(\boldsymbol{C}$, D) were prepared. Red arrows indicate notable human ASN aggregation. Dotted red lines show the area of the substantia nigra.

months (3.3) was higher than that for the noncarrier group, which then sharply decreased with age: at 16 months, the A53T- $\mathrm{Tg}$ group $\mathrm{BP}_{\mathrm{ND}}$ value showed a $43 \%$ decline (1.9) compared with $A 53 T-T g$ rats at 4 months. The dynamic changes of $\left[{ }^{11} \mathrm{C}\right] \mathrm{ITDM} \mathrm{BP}_{\mathrm{ND}}$ in $A 53 \mathrm{~T}-\mathrm{Tg}$ group were also significantly 

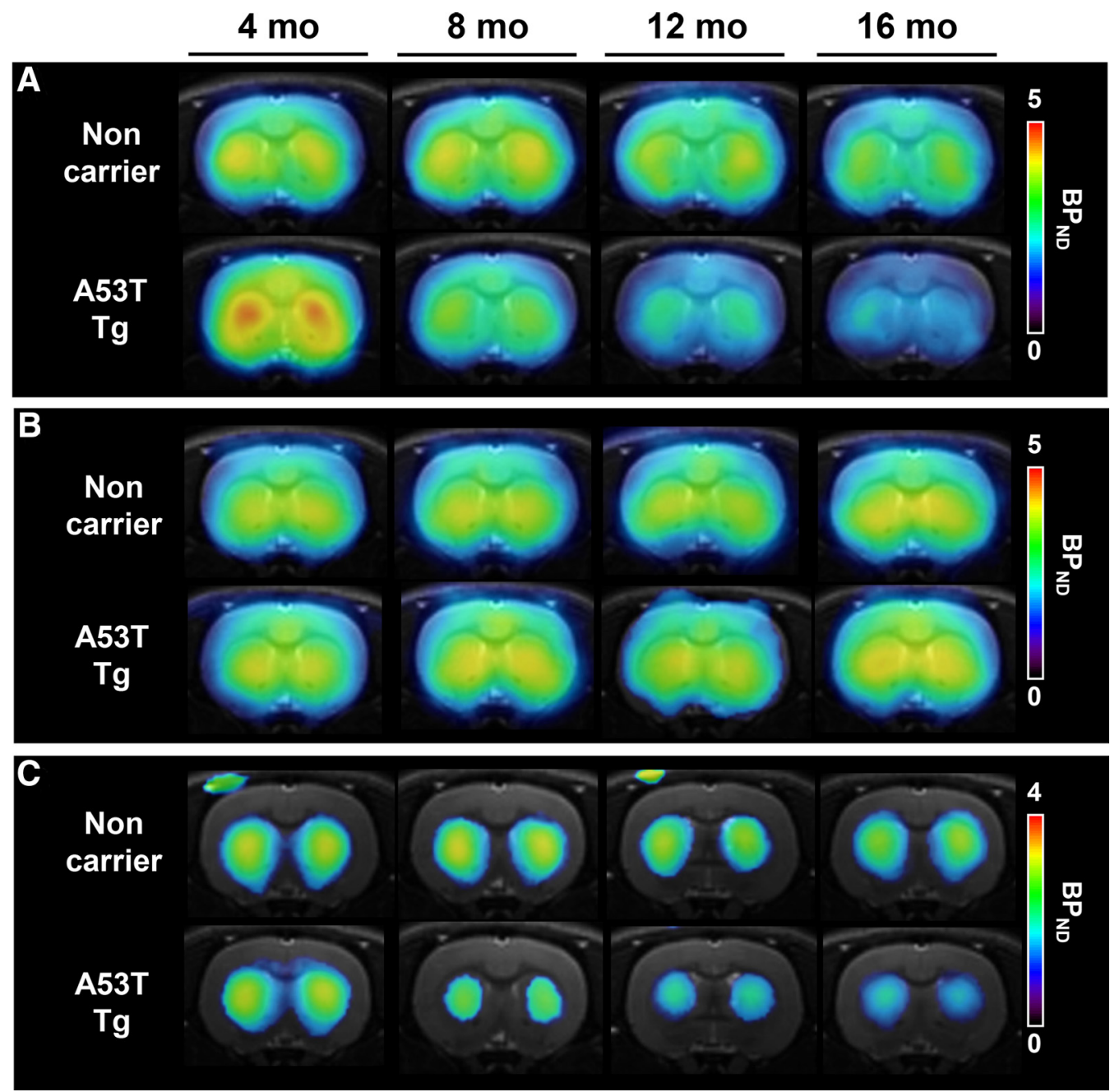

Figure 5. Representative parametric PET and MRI images for mGluR1, mGluR5, and DAT at 4, 8,12 , and 16 months in the striatum of the same noncarrier (top) and $A 53 T-T g$ (bottom) rats. $A$, Parametric images based on mGluR1 BP ${ }_{\mathrm{ND}}$ using $\left[{ }^{11} \mathrm{C}\right] \mathrm{ITDM}$. B, Parametric images based on mGluR5 BP ${ }_{\mathrm{ND}}$ using $(E)-\left[{ }^{11} \mathrm{C}\right] \mathrm{ABP} 688$. C, Parametric images based on BP ${ }_{\mathrm{ND}}$ using $\left[{ }^{18} \mathrm{~F}\right] \mathrm{FE}-\mathrm{PE} 21$. All slices were located $-0.12 \mathrm{~mm}$ from bregma.
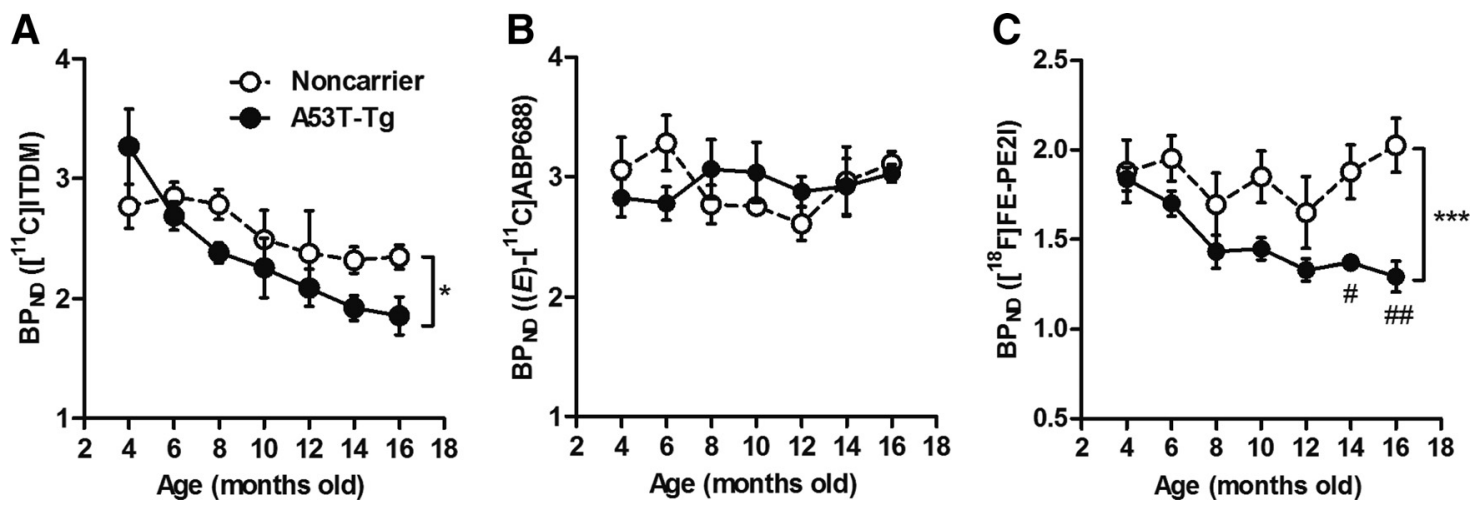

Figure 6. Dynamic changes in striatal $B P_{\mathrm{ND}}$ values in 4- to 16 -month-old noncarrier and $A 53 T$ - $T g$ rats. $A, B P_{N D}$ values represent mGluR1-specific binding to $\left[{ }^{11} \mathrm{C}\right] \mathrm{ITDM}(48-67 \mathrm{MBq}, 0.2-0.9$ $\mathrm{nmol}) . B, B P_{\mathrm{ND}}$ values represent mGluR5-specific binding to (E)-[ $\left.{ }^{11} \mathrm{C}\right] \mathrm{ABP} 688(40-54 \mathrm{MBq}, 0.1-0.6 \mathrm{nmol}) . C$, BP $\mathrm{ND}_{\mathrm{ND}}$ values represent DAT-specific binding to [ $\left.{ }^{18} \mathrm{~F}\right] \mathrm{FE}-\mathrm{PE} 2 \mathrm{l}(11-16 \mathrm{MBq}, 0.1-1.2$ nmol). ${ }^{*} p<0.05,{ }^{* * *} p<0.001$ (two-way ANOVAs); ${ }^{\#} p<0.05$, ${ }^{\# \#} p<0.01$ (post hoc analyses). For noncarrier rats, $n=4$ per time point. For $A 53 T-\operatorname{Tg}$ rats, $n=6$ at $4,6,8$, and 10 months; $n=$ 4 at 12,14 , and 16 months.

larger than that in the noncarrier group $(p=0.049)$. In contrast, $(E)-\left[{ }^{11} \mathrm{C}\right] \mathrm{ABP} 688 \mathrm{BP}_{\mathrm{ND}}$ values (indicating mGluR5 levels) in both groups were maintained at values of $\sim 3$ during the experimental term, and no differences $(p>0.05)$ between groups were identified at any experimental age. At 12 to 16 months, $(E)$ - $\left[{ }^{11} \mathrm{C}\right] \mathrm{ABP} 688 \mathrm{BP}_{\mathrm{ND}}$ values tended to increase in noncarrier rats; however, there were no significant differences $(p>0.05)$ between groups. At 4 months, $\left[{ }^{18} \mathrm{~F}\right] \mathrm{FE}-\mathrm{PE} 2 \mathrm{I} \mathrm{BP}_{\mathrm{ND}}$ values were 1.9 and 1.8 for noncarrier and $A 53 T-T g$ rats, respectively. Among A53T- $T g$ rats, $\left[{ }^{18} \mathrm{~F}\right] \mathrm{FE}-\mathrm{PE} 2 \mathrm{I} \mathrm{BP}_{\mathrm{ND}}$ values dramatically decreased 
with age and showed significant differences from those in age-matched noncarrier groups $(p<0.0001)$. In contrast, values for noncarrier rats slightly declined until they reached 12 months of age, and tended to increase afterward. The overall $\left[{ }^{18} \mathrm{~F}\right] \mathrm{FE}-\mathrm{PE} 2 \mathrm{I} \mathrm{BP}_{\mathrm{ND}}$ signal in A53T$\mathrm{Tg}$ rats decreased by $29 \%$ from 4 to 16 months.

To validate changes in $\mathrm{BP}_{\mathrm{ND}}$ values in PET studies, in vitro autoradiography was performed using brain sections from 16month-old rats. As shown in Figure 7, striatal binding of $\left[{ }^{11} \mathrm{C}\right] \operatorname{ITDM}(p<$ $0.0001)$ and $\left[{ }^{18} \mathrm{~F}\right] \mathrm{FE}-\mathrm{PE} 2 \mathrm{I}(p=0.0002)$ in autoradiograms from $A 53 T-T g$ rat brain sections were significantly lower than those of noncarrier rat brain sections. In contrast, there was no difference ( $p=$ $0.0805)$ in striatal binding of $(E)$ $\left[{ }^{11} \mathrm{C}\right] \mathrm{ABP} 688$ between groups. These in vitro results strongly support that the in vivo decline of $\left[{ }^{11} \mathrm{C}\right] \mathrm{ITDM}$ and $\left[{ }^{18} \mathrm{~F}\right] \mathrm{FE}-$ PE2I BP ${ }_{\mathrm{ND}} \mathrm{S}$ in the striatum of $A 53 T-T g$ rat reflected decrease of mGluR1 and DAT densities.

\section{Correlation between general motor activities and striatal $\mathrm{BP}_{\mathrm{ND}}$ values for radioligands}

Scatter plots between motor activities (locomotion and rearing) and striatal $\mathrm{BP}_{\mathrm{ND}}$ values for $\left[{ }^{11} \mathrm{C}\right] \mathrm{ITDM},(E)-\left[{ }^{11} \mathrm{C}\right] \mathrm{ABP} 688$, and $\left[{ }^{18} \mathrm{~F}\right] \mathrm{FE}-\mathrm{PE} 2 \mathrm{I}$ are shown in Figure $8 . \mathrm{BP}_{\mathrm{ND}}$ values for $\left[{ }^{11} \mathrm{C}\right] \mathrm{ITDM}$ had the highest correlation with motor activities (indicating an association with mGluR1), with correlation coefficients $(r)$ of $0.780(p<0.0001)$ and 0.546 ( $p=0.0008)$ for locomotion and rearing, respectively. Relatively high correlations were also found between locomotion $(r=$ $0.639, p<0.0001)$ or rearing $(r=0.469, p=0.0034)$ and $\left[{ }^{18} \mathrm{~F}\right] \mathrm{FE}-\mathrm{PE} 2 \mathrm{I} \mathrm{BP}_{\mathrm{ND}}$ values, indicating an association with DAT levels. However, no correlation (locomotion, $r=0.007, p=$ 0.9673 ; rearing, $r=-0.110, p=0.5492$ ) was observed between motor activities and mGluR5-related $(E)-\left[{ }^{11} \mathrm{C}\right] \mathrm{ABP} 688 \mathrm{BP}_{\mathrm{ND}}$ values.

To identify whether declines in mGluR1 levels were associated with dopaminergic neuron degeneration, scatter plot analyses between $\left[{ }^{11} \mathrm{C}\right]$ ITDM and $\left[{ }^{18} \mathrm{~F}\right] \mathrm{FE}-\mathrm{PE} 2 \mathrm{I} \mathrm{BP}_{\mathrm{ND}}$ values were performed. Figure 9 shows scatter plots with a linear regression between binding data for mGluR1 and DAT. A correlation coefficient of 0.395 ( $p=0.0308$ ) was detected between $\left[{ }^{11} \mathrm{C}\right]$ ITDM and $\left[{ }^{18} \mathrm{~F}\right] \mathrm{FE}-\mathrm{PE} 2 \mathrm{I} \mathrm{BP}_{\mathrm{ND}}$ values, suggesting that the decline in mGluR1 levels was partially correlated with dopaminergic neuron degeneration.

Dynamic changes of $\left[{ }^{11} \mathrm{C}\right] \mathrm{ITDM} \mathrm{BP}_{\mathrm{ND}}$ values in brain regions of $A 53 T$ - $T g$ rats.

The percentage change in $\left[{ }^{11} \mathrm{C}\right] \mathrm{ITDM} \mathrm{BP}_{\mathrm{ND}}$ values with age $(4,8$, 12 , and 16 months) in the striatum, hippocampus, cingulate cortex, thalamus, and cerebellum in $A 53 T-T g$ rats compared with noncarrier rats is shown in Figure 10 . The $\mathrm{BP}_{\mathrm{ND}}$ values in all brain regions of $A 53 \mathrm{~T}-\mathrm{Tg}$ rats increased $15-30 \%$ at 4 months compared with noncarrier rats, and then recovered to a similar level in the cingulate cortex, thalamus, and cerebellum compared with non-
B

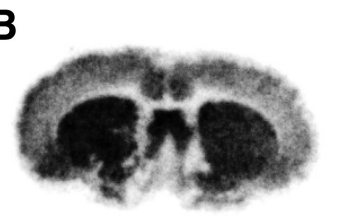

C

E

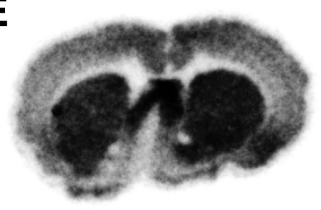

$\mathbf{F}$

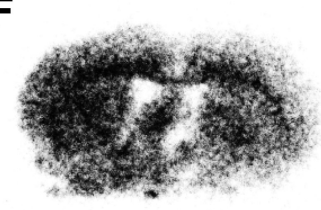

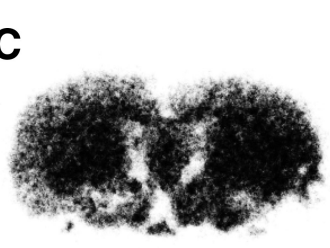

Figure 7. $\quad \boldsymbol{A}-\boldsymbol{D}$, In vitro autoradiography using noncarrier $(\boldsymbol{A}-\boldsymbol{C})$ and $A 53 T-\operatorname{Tg}(\boldsymbol{D}-\boldsymbol{F})$ rat brain sections. $\boldsymbol{A}, \boldsymbol{D}$, Autoradiograms

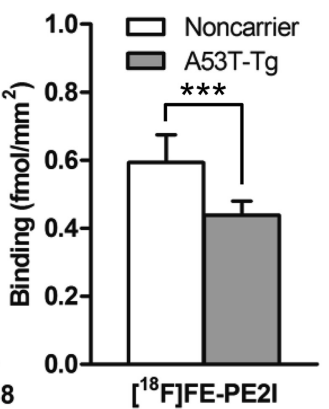

(E)-[ $\left.{ }^{11} \mathrm{C}\right] A B P 688$

$\left[{ }^{18}\right.$ F]FE-PE2

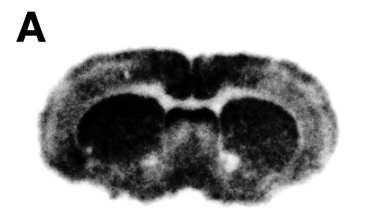

use ["] Autoradiograms use [ ${ }^{18} \mathrm{~F}$ ]FE-PE2I $(0.7 \mathrm{MBq}, 16.5 \mathrm{pm})$ for DAT. G, Quantitative measurements (femtomoles per square millimeter) of binding for each radioligand on brain sections. ${ }^{* *} p<0.001$ (Student's $t$ test).

carrier rats. In contrast, $\mathrm{BP}_{\mathrm{ND}}$ values in the striatum and hippocampus decreased by $10-15 \%$ during $4-8$ months compared with noncarrier rats. $\mathrm{BP}_{\mathrm{ND}}$ values in the hippocampus recovered to noncarrier rat levels, whereas striatal $\mathrm{BP}_{\mathrm{ND}}$ values continued to decrease with age.

\section{Evaluation of cerebellar $\left[{ }^{11} \mathrm{C}\right] \mathrm{ITDM} \mathrm{BP}_{\mathrm{ND}}$ values in} noncarrier and $A 53 T-T g$ rats

To confirm whether changes in cerebellar mGluR1 levels, which express with the highest density in the rat brain, are related to PD progression, scatter plot analyses were performed across ages comparing cerebellar mGluR1 $\mathrm{BP}_{\mathrm{ND}}$ values and locomotion scores for noncarrier and $A 53 \mathrm{~T}-\mathrm{Tg}$ rats. Longitudinal changes in cerebellar [ $\left.{ }^{11} \mathrm{C}\right] \mathrm{ITDM} \mathrm{BP}_{\mathrm{ND}}$ values and their correlation with locomotion are shown in Figure 11. Cerebellar $\left[{ }^{11} \mathrm{C}\right] \mathrm{ITDM} B \mathrm{P}_{\mathrm{ND}}$ values showed moderate decreases with age in both groups. Unlike striatal $\mathrm{BP}_{\mathrm{ND}}$ values of $\left[{ }^{11} \mathrm{C}\right] \mathrm{ITDM}$, no differences between noncarrier and $A 53 T-T g$ rats were observed. Additionally, a relatively poor correlation $(r=0.281, p=0.0648)$ was observed between locomotion and cerebellar $\mathrm{BP}_{\mathrm{ND}}$ values of $\left[{ }^{11} \mathrm{C}\right] \mathrm{ITDM}$.

\section{Discussion}

In the present study, we demonstrated that dynamic changes occur in mGluR1, but not mGluR5 levels, in rat brains using a chronic-PD-model paradigm through longitudinal PET imaging. Interestingly, the changes in mGluR1 expression were strongly associated with the progression of PD pathology.

We used $\mathrm{BP}_{\mathrm{ND}}$ values obtained by PET to quantitatively estimate the densities of target molecules in vivo. The $\mathrm{BP}_{\mathrm{ND}}$ was obtained from PET imaging according to in vitro radioligand binding, which provided quantitative values that correspond to the target molecule (receptors, transporters, or enzymes) expres- 
A

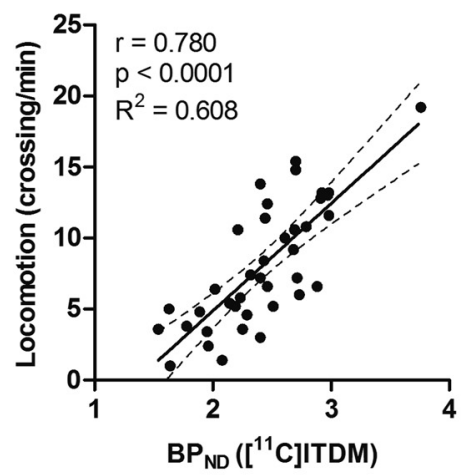

D

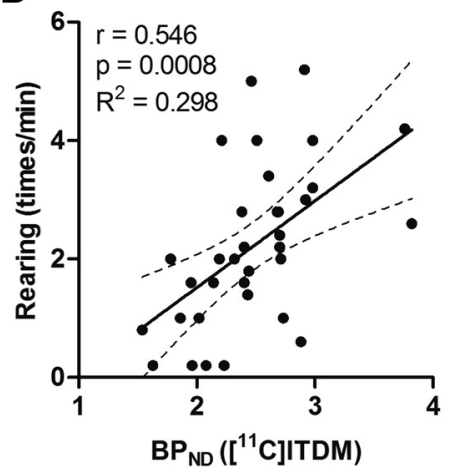

B

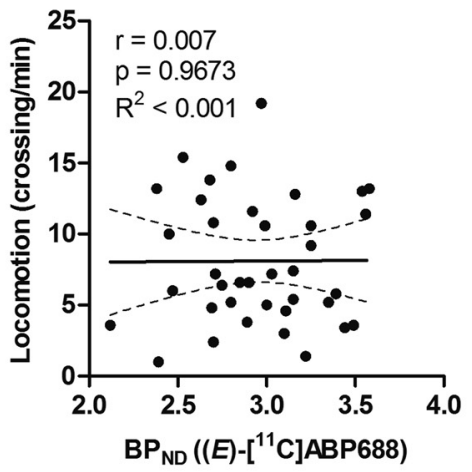

$\mathbf{E}$

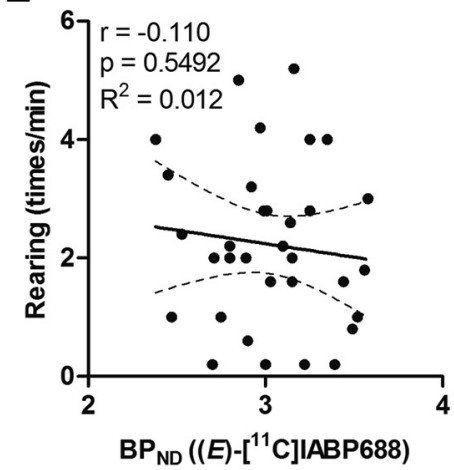

C

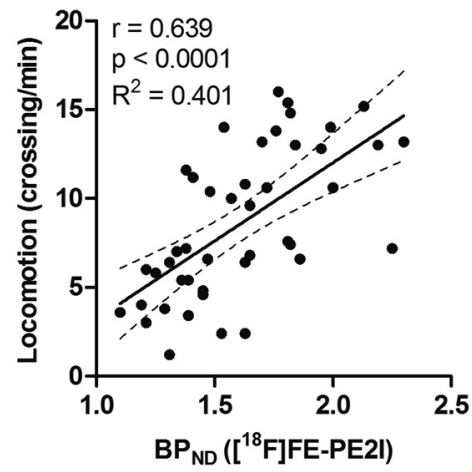

$\mathbf{F}$

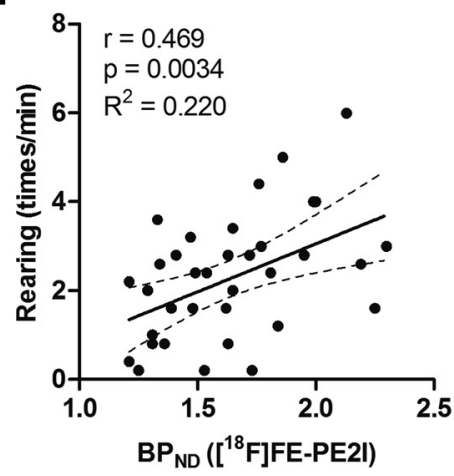

Figure 8. Scatter plots between general motor activities and $B P_{N D}$ values. $A$, Locomotion plotted against $\left[{ }^{11} \mathrm{C}\right] \mathrm{ITDM} B \mathrm{P}_{\mathrm{ND}}$ values specific to mGluR1. $B$, Locomotion plotted against ( $E$ )-

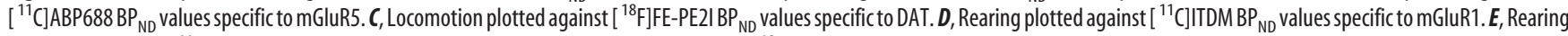
plotted against $(E)-\left[{ }^{11} \mathrm{C}\right] A B P 688 \mathrm{BP}_{\mathrm{ND}}$ values specific to mGluR5. $\boldsymbol{F}$, Rearing plotted against $\left[{ }^{18} \mathrm{~F}\right] \mathrm{FE}-\mathrm{PE} 2 \mathrm{BP}{ }_{\mathrm{ND}}$ values specific to DAT. The regression lines in each graph show the $95 \%$ confidence intervals (dotted lines). Respective correlation coefficients $(r), p$ values, and $R^{2}$ values are shown adjacent to each scatter plot.

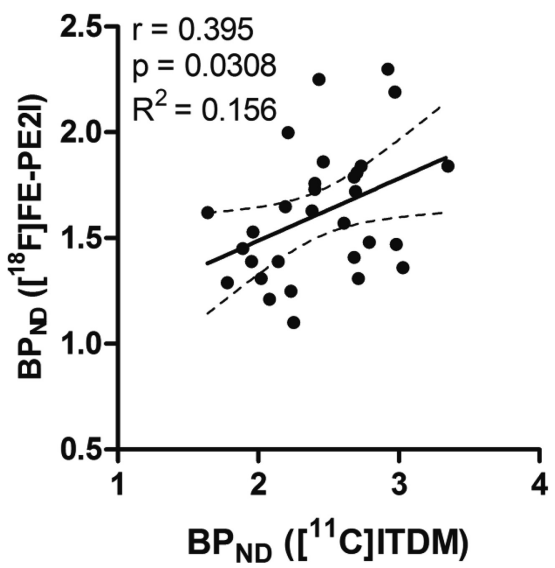

Figure 9. Scatter plot depicting $\mathrm{BP}_{\mathrm{ND}}$ values compared between with $\left[{ }^{11} \mathrm{C}\right] \mathrm{TDDM}$ (specific to mGluR1) and $\left[{ }^{18} \mathrm{~F}\right] \mathrm{FE}-\mathrm{PE} 2 \mathrm{l}$ (specific to DAT). The regression line shows $95 \%$ confidence intervals (dotted lines). The correlation coefficient $(r), p$ value, and $R^{2}$ value from our analysis are shown adjacent to the scatter plot.

sion in the tissue (Mintun et al., 1984). The $\mathrm{BP}_{\mathrm{ND}}$ was defined as the ratio of a specifically bound radioligand to that of a nondisplaceable (free and nonspecific binding) radioligand in the tissue at equilibrium state. This is a standard method used to measure the input function based on a target-negligible region as a reference, instead of using an artery blood-sampling method. The use of $\mathrm{BP}_{\mathrm{ND}}$ values allows for convenient and noninvasive assessment of target molecule densities and enables longitudinal PET imaging. Previously, we demonstrated that $\mathrm{BP}_{\mathrm{ND}}$ values based on PET with $\left[{ }^{11} \mathrm{C}\right]$ ITDM were highly correlated with immunohisto- chemical signals measuring mGluR1 expression in the brains of rodents (Yamasaki et al., 2014). In PET studies using (E)$\left[{ }^{11} \mathrm{C}\right] \mathrm{ABP} 688$, the $\mathrm{BP}_{\mathrm{ND}}$ value was also frequently used to quantify mGluR5 expression in vivo (Wyckhuys et al., 2013; Choi et al., 2014; Mathews et al., 2014). Additionally, the $\left[{ }^{18} \mathrm{~F}\right] \mathrm{FE}-\mathrm{PE} 2 \mathrm{I} \mathrm{BP}_{\mathrm{ND}}$ value has been widely used as a biomarker for dopaminergic neurons in clinical PET studies (Sasaki et al., 2012; Kim et al., 2014; Suzuki et al., 2014). Thus, the previous reports provide strong evidence that $\mathrm{BP}_{\mathrm{ND}}$ values can be used to quantitatively measure the mGluR1, mGluR5, and DAT densities in our present study.

Genetic aberrations in ASN, including point mutations (A53T, $A 30 P$, and $E 46 K$ ) and multiplications, have been linked to familial PD and Lewy-body dementia (Polymeropoulos et al., 1997). These mutations generally occur in the $N$-terminal amphipathic region of the protein, resulting in the formation of insoluble filaments. Among the various genetic aberrations, A53T is the most frequent mutation in familial Parkinsonism, and results in an earlier onset than that observed in most cases of sporadic PD (Cookson et al., 2005). In this study, we used mutant rats overexpressing human A53T-ASN as a chronic model of PD. Motor activities (as defined by behavioral scores) in A53T- $\mathrm{Tg}$ rats showed declines of $\sim 50 \%$ at 10 months, and at 16 months, most $A 53 T-T g$ rats exhibited significantly lower motor activities (Fig. 3). As assessed by immunohistochemistry, A53T-Tg rats with low motor activities showed abnormal aggregations of human ASN and degeneration of dopaminergic neurons in the striatum (Fig. 4).

In our longitudinal PET experiments, dynamic changes with age were observed in $\mathrm{BP}_{\mathrm{ND}}$ values for $\left[{ }^{11} \mathrm{C}\right] \mathrm{ITDM}$, but not $(E)$ $\left[{ }^{11} \mathrm{C}\right] \mathrm{ABP} 688$, in $\mathrm{A53T}-\mathrm{Tg}$ rats (Figs. 5, 6). Interestingly, striatal $\left[{ }^{11} \mathrm{C}\right] \mathrm{ITDM} \mathrm{BP}_{\mathrm{ND}}$ values were higher in $\mathrm{A53T-Tg}$ rats than non- 
carrier rats before onset of $\mathrm{PD}$ pathology, but subsequently decreased dramatically with age. These changes were highly correlated with dynamic changes in motor activities (Fig. 8). It was reported previously that abnormal ASN aggregation resulted in hypertrophy of striatal glutamatergic nerve terminals and increased glutamate release into the synaptic cleft (Nakata et al., 2012). Thus, the observed initial mGluR1 expression increases in 4-month-old A53T- $\mathrm{Tg}$ rats may be caused by the excessive glutamate release associated with abnormal ASN accumulation. Additionally, mGluR1 is prominently expressed in the dopaminergic neurons of the substantia nigra pars compacta, where subsequent activation facilitates somatodendritic dopamine release via intracellular calcium mobilization (Testa et al., 1994; Patel et al., 2009). Together, these data suggest that mGluR1 overactivations located on dopaminergic neurons stimulate excessive dopamine release and induce a transient increase in motor activity in young (4- to 5-month-old) $A 53 \mathrm{~T}-\mathrm{Tg}$ rats. However, $\left[{ }^{18} \mathrm{~F}\right] \mathrm{FE}-\mathrm{PE} 2 \mathrm{I} \mathrm{BP}_{\mathrm{ND}}$ values associated with DAT availability showed no change in relation to the temporary activation of motor activities before PD onset. This result suggests that dopamine increases without concurrent alterations in synaptic cleft DAT availability enhance neurotransmission, further stimulating dopamine signaling. Consequently, these abnormalities might induce dopaminergic neuron degeneration via unknown mechanisms. More importantly, these data suggest that the dynamic decline we observed in mGluR1 expression reflected the subsequent activation and degeneration of dopaminergic neurons.

Although dramatic decreases in striatal mGluR1 after PD onset were shown in $A 53 T-T g$ rats, gradual declines in mGluR1 expression were exhibited in the noncarrier rat with age. The age-

dependent reduction in the functional responses of striatal group I metabotropic glutamate receptors was demonstrated previously (Pintor et al., 2000). It was also reported that mGluR5 protein expression in brain regions remained unchanged during aging (Simonyi et al., 2005). Thus, these reports are consistent with our findings that expression of mGluR1, but not mGluR5, decreased by unknown mechanisms associated with aging. Interestingly, although the observed mGluR1 expression decline in the cerebellum, the mGluR1-richest region without dopaminergic neurons, was poorly correlated with motor activities (Fig. 11), striatal mGluR1 decreases were highly correlated with motor activities. Thus, striatal mGluR1 expression is a potential in vivo biomarker for PD diagnosis.

Previously, multi-PET studies for dopaminergic neurons and mGluR5 were performed using 6-OHDA-lesioned rats as an

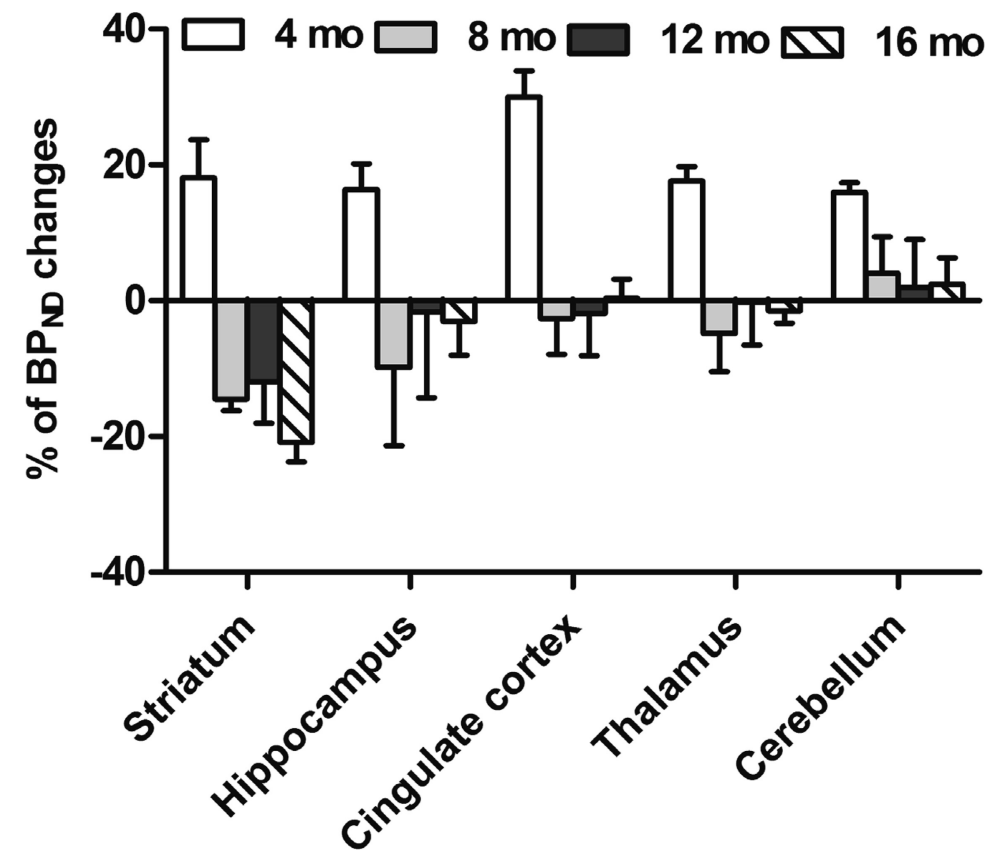

Figure 10. Percentage of regional change in $\mathrm{BP}_{\mathrm{ND}}$ with [ $\left.{ }^{11} \mathrm{C}\right] \mathrm{ITDM}$ in $A 53 \mathrm{~T}$-Tg rats at $4,8,12$, and 16 months compared with same-aged noncarrier rats. Regions of interest were selected on mGluR1-rich regions, such as the striatum, hippocampus, cingu-
A

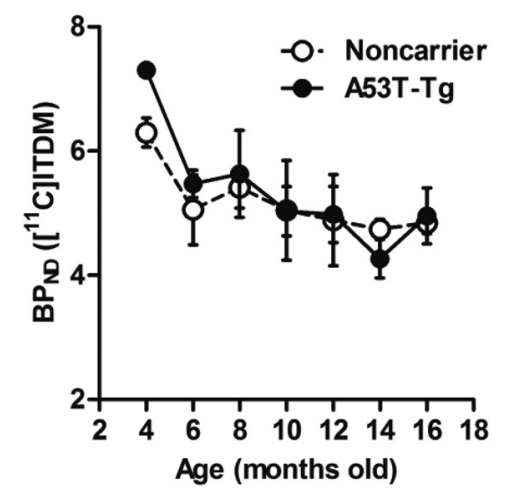

B

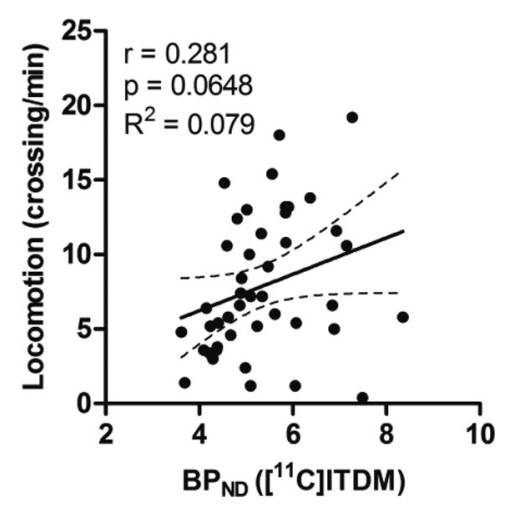

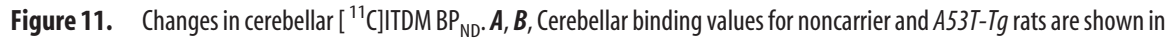
relation to age $(\boldsymbol{A})$ and as correlation plots against locomotion $(\boldsymbol{B})$. The regression line shows $95 \%$ confidence intervals (dotted lines), with correlation coefficients $(r), p$ values, and $R^{2}$ values from our analysis. For noncarrier rats, $n=4$ in each time point. For A53T-Tg rats, $n=6$ at $4,6,8$, and 10 months; $n=4$ at 12,14 , and 16 months.

acute PD model (Pellegrino et al., 2007). In the study by Pellegrino et al. (2007), $\mathrm{BP}_{\mathrm{ND}}$ values for mGluR5 in the lesioned side of the striatum increased concurrently with dopaminergic neuron degeneration. However, in the present study, striatal mGluR5 $\mathrm{BP}_{\mathrm{ND}}$ values in rats with aggregated abnormal ASN remained unchanged during PD symptom progression. In the acute model, mGluR5 expression upregulation may be the result of signaling cascades that induce neuronal death. In accordance with this view, mGluR5 knock-out mice have decreased dopaminergic neuron degeneration following 6-OHDA treatment (Black et al., 2010). Together, these data suggest that mGluR1 and mGluR5 may have distinct functions in acute, compared with chronic, toxicity in the CNS. The present findings contribute to the understanding of pathogenic mechanisms in several CNS disorders and suggest mGluR1 may be a potential therapeutic target for PD. 
At present, several studies have reported a decline in DAT density among aged rodents (Himi et al., 1995; Salvatore et al., 2003; Niñerola-Baizán et al., 2015). We reported a gradual decrease in $\left[{ }^{18} \mathrm{~F}\right] \mathrm{FE}-\mathrm{PE} 2 \mathrm{I} \mathrm{BP}_{\mathrm{ND}}$ values among noncarrier rats until they were 12 months old, which then increased until the age of 16 months. However, reported $\mathrm{BP}_{\mathrm{ND}}$ values from noncarrier rats showed large error margins, particularly among rats that were 8 and 12 months old. Additionally, no obvious age-dependent decline in DAT availability was detected before middle age in the Sprague Dawley rat strain. More importantly, the $\left[{ }^{18} \mathrm{~F}\right] \mathrm{FE}-\mathrm{PE} 2 \mathrm{I}$ $\mathrm{BP}_{\mathrm{ND}}$ values from $A 53 T-\mathrm{Tg}$ rats reflected DAT availability and corresponded with PD pathology.

In conclusion, in this longitudinal PET study, we have demonstrated for the first time that dynamic changes associated with PD progression occur in the expression of mGluR1, but not mGluR5, in a chronic PD model of rats that mimics clinical pathology. We therefore suggest that mGluR1 is a useful in vivo biomarker to further the understanding of pathological mechanisms in PD. These findings may also facilitate the development of pharmaceuticals targeting mGluR1 for the treatment of PD and many other CNS disorders.

\section{References}

Abe T, Sugihara H, Nawa H, Shigemoto R, Mizuno N, Nakanishi S (1992) Molecular characterization of a novel metabotropic glutamate receptor mGluR5 coupled to inositol phosphate/ $\mathrm{Ca}^{2+}$ signal transduction. J Biol Chem 267:13361-13368. Medline

Aguirre JA, Andbjer B, González-Barón S, Hansson A, Strömberg I, Agnati LF, Fuxe K (2001) Group I mGluR antagonist AIDA protects nigral DA cells from MPTP-induced injury. Neuroreport 12:2615-2617. CrossRef Medline

Aramori I, Nakanishi S (1992) Signal transduction and pharmacological characteristics of a metabotropic glutamate receptor, mGluR1, in transfected CHO cells. Neuron 8:757-765. CrossRef Medline

Bao WL, Williams AJ, Faden AI, Tortella FC (2001) Selective mGluR5 receptor antagonist or agonist provides neuroprotection in a rat model of focal cerebral ischemia. Brain Res 922:173-179. CrossRef Medline

Black YD, Xiao D, Pellegrino D, Kachroo A, Brownell AL, Schwarzschild MA (2010) Protective effect of metabotropic glutamate mGluR5 receptor elimination in a 6-hydroxydopamine model of Parkinson's disease. Neurosci Lett 486:161-165. CrossRef Medline

Choi H, Kim YK, Oh SW, Im HJ, Hwang do W, Kang H, Lee B, Lee YS, Jeong JM, Kim EE, Chung JK, Lee DS (2014) In vivo imaging of mGluR5 changes during epileptogenesis using $\left[{ }^{11} \mathrm{C}\right] \mathrm{ABP} 688$ PET in pilocarpineinduced epilepsy rat model. PLoS One 9:e92765. CrossRef Medline

Cookson MR, Xiromerisiou G, Singleton A (2005) How genetics research in Parkinson's disease is enhancing understanding of the common idiopathic forms of the disease. Current Opinion in Neurology 18:706-711. CrossRef Medline

Dekundy A, Pietraszek M, Schaefer D, Cenci MA, Danysz W (2006) Effects of group I metabotropic glutamate receptors blockade in experimental models of Parkinson's disease. Brain Res Bull 69:318-326. CrossRef Medline

De Leonibus E, Managò F, Giordani F, Petrosino F, Lopez S, Oliverio A, Amalric M, Mele A (2009) Metabotropic glutamate receptors 5 blockade reverses spatial memory deficits in a mouse model of Parkinson's disease. Neuropsychopharmacology 34:729-738. CrossRef Medline

Elmenhorst D, Minuzzi L, Aliaga A, Rowley J, Massarweh G, Diksic M, Bauer A, Rosa-Neto P (2010) In vivo and in vitro validation of reference tissue models for the mGluR $\mathrm{m}_{5}$ ligand $\left[{ }^{11} \mathrm{C}\right] \mathrm{ABP} 688$. J Cereb Blood Flow Metab 30:1538-1549. CrossRef Medline

Ferraguti F, Crepaldi L, Nicoletti F (2008) Metabotropic glutamate 1 receptor: current concepts and perspectives. Pharmacol Rev 60:536-581. CrossRef Medline

Fotuhi M, Sharp AH, Glatt CE, Hwang PM, von Krosigk M, Snyder SH, Dawson TM (1993) Differential localization of phosphoinositidelinked metabotropic glutamate receptor (mGluR1) and the inositol 1,4,5trisphosphate receptor in rat brain. J Neurosci 13:2001-2012. Medline

Francesconi A, Duvoisin RM (1998) Role of the second and third intracel- lular loops of metabotropic glutamate receptors in mediating dual signal transduction activation. J Biol Chem 273:5615-5624. CrossRef Medline

Fujinaga M, Yamasaki T, Maeda J, Yui J, Xie L, Nagai Y, Nengaki N, Hatori A, Kumata K, Kawamura K, Zhang MR (2012) Development of N-[4-[6(isopropylamino)pyrimidin-4-yl]-1,3-thiazol-2-yl]-N-methyl-4-[ $\left.{ }^{11} \mathrm{C}\right]$ methylb enzamide for positron emission tomography imaging of metabotropic glutamate 1 receptor in monkey brain. J Med Chem 55:11042-11051. CrossRef Medline

Himi T, Cao M, Mori N (1995) Reduced expression of the molecular markers of dopaminergic neuronal atrophy in the aging rat brain. J Gerontol A Biol Sci Med Sci 50:B193-B200. Medline

Kaneda K, Tachibana Y, Imanishi M, Kita H, Shigemoto R, Nambu A, Takada M (2005) Down-regulation of metabotropic glutamate receptor lalpha in globus pallidus and substantia nigra of parkinsonian monkeys. Eur J Neurosci 22:3241-3254. CrossRef Medline

Kawamura K, Yamasaki T, Kumata K, Furutsuka K, Takei M, Wakizaka H, Fujinaga M, Kariya K, Yui J, Hatori A, Xie L, Shimoda Y, Hashimoto H, Hayashi K, Zhang MR (2014) Binding potential of (E)-[ $\left.{ }^{11} \mathrm{C}\right] \mathrm{ABP} 688$ to metabotropic glutamate receptor subtype 5 is decreased by the inclusion of its ${ }^{11}$ C-labelled Z-isomer. Nucl Med Biol 41:17-23. CrossRef Medline

Kim W, Tateno A, Arakawa R, Sakayori T, Ikeda Y, Suzuki H, Okubo Y (2014) In vivo activity of modafinil on dopamine transporter measured with positron emission tomography and $\left[{ }^{18} \mathrm{~F}\right]$ FE-PE2I. Int J Neuropsychopharmacol 17:697-703. CrossRef Medline

Kohara A, Takahashi M, Yatsugi S, Tamura S, Shitaka Y, Hayashibe S, Kawabata S, Okada M (2008) Neuroprotective effects of the selective type 1 metabotropic glutamate receptor antagonist YM-202074 in rat stroke models. Brain Res 1191:168-179. CrossRef Medline

Lammertsma AA, Hume SP (1996) Simplified reference tissue model for PET receptor studies. Neuroimage 4:153-158. CrossRef Medline

Logan J, Fowler JS, Volkow ND, Wang GJ, Ding YS, Alexoff DL (1996) Distribution volume ratios without blood sampling from graphical analysis of PET data. J Cereb Blood Flow Metab 16:834-840. Medline

Löscher W, Dekundy A, Nagel J, Danysz W, Parsons CG, Potschka H (2006) mGlu1 and mGlu5 receptor antagonists lack anticonvulsant efficacy in rodent models of difficult-to-treat partial epilepsy. Neuropharmacology 50:1006-1015. CrossRef Medline

Mathews WB, Kuwabara H, Stansfield K, Valentine H, Alexander M, Kumar A, Hilton J, Dannals RF, Wong DF, Gasparini F (2014) Dosedependent, saturable occupancy of the metabotropic glutamate subtype 5 receptor by fenobam as measured with $\left[{ }^{11} \mathrm{C}\right] \mathrm{ABP} 688$ PET imaging. Synapse. Advance online publication. doi:10.1002/syn.21775.

Mintun MA, Raichle ME, Kilbourn MR, Wooten GF, Welch MJ (1984) A quantitative model for the in vivo assessment of drug binding sites with positron emission tomography. Ann Neurol 15:217-227. CrossRef Medline

Nakanishi S, Nakajima Y, Masu M, Ueda Y, Nakahara K, Watanabe D, Yamaguchi S, Kawabata S, Okada M (1998) Glutamate receptors: brain function and signal transduction. Brain Res Rev 26:230-235. CrossRef Medline

Nakata Y, Yasuda T, Fukaya M, Yamamori S, Itakura M, Nihira T, Hayakawa H, Kawanami A, Kataoka M, Nagai M, Sakagami H, Takahashi M, Mizuno Y, Mochizuki H (2012) Accumulation of alpha-synuclein triggered by presynaptic dysfunction. J Neurosci 32:17186-17196. CrossRef Medline

Niñerola-Baizán A, Rojas S, Roé-Vellvé N, Lomeña F, Ros D, Pavía J (2015) Dopamine transporter imaging in the aged rat: a $\left[{ }^{123} \mathrm{I}\right] \mathrm{FP}-\mathrm{CIT}$ SPECT study. Nucl Med Biol 42:395-398. CrossRef Medline

Patel JC, Witkovsky P, Avshalumov MV, Rice ME (2009) Mobilization of calcium from intracellular stores facilitates somatodendritic dopamine release. J Neurosci 29:6568-6579. CrossRef Medline

Pellegrino D, Cicchetti F, Wang X, Zhu A, Yu M, Saint-Pierre M, Brownell AL (2007) Modulation of dopaminergic and glutamatergic brain function: PET studies on parkinsonian rats. J Nucl Med 48:1147-1153. CrossRef Medline

Pintor A, Potenza RL, Domenici MR, Tiburzi F, Reggio R, Pèzzola A, Popoli P (2000) Age-related decline in the functional response of striatal group I mGlu receptors. Neuroreport 11:3033-3038. CrossRef Medline

Polymeropoulos MH, Lavedan C, Leroy E, Ide SE, Dehejia A, Dutra A, Pike B, Root H, Rubenstein J, Boyer R, Stenroos ES, Chandrasekharappa S, Athanassiadou A, Papapetropoulos T, Johnson WG, Lazzarini AM, Duvoisin RC, Di Iorio G, Golbe LI, Nussbaum RL (1997) Mutation in the alpha- 
synuclein gene identified in families with Parkinson's disease. Science 276:2045-2047. CrossRef Medline

Roberts HL, Brown DR (2015) Seeking a mechanism for the toxicity of oligomeric alpha-synuclein. Biomolecules 5:282-305. CrossRef Medline

Rylander D, Iderberg H, Li Q, Dekundy A, Zhang J, Li H, Baishen R, Danysz W, Bezard E, Cenci MA (2010) A mGluR5 antagonist under clinical development improves L-DOPA-induced dyskinesia in parkinsonian rats and monkeys. Neurobiol Dis 39:352-361. CrossRef Medline

Salvatore MF, Apparsundaram S, Gerhardt GA (2003) Decreased plasma membrane expression of striatal dopamine transporter in aging. Neurobiol Aging 24:1147-1154. CrossRef Medline

Samadi P, Grégoire L, Morissette M, Calon F, Hadj Tahar A, Dridi M, Belanger N, Meltzer LT, Bédard PJ, Di Paolo T (2008) mGluR5 metabotropic glutamate receptors and dyskinesias in MPTP monkeys. Neurobiol Aging 29:1040-1051. CrossRef Medline

Sanchez-Pernaute R, Wang JQ, Kuruppu D, Cao L, Tueckmantel W, Kozikowski A, Isacson O, Brownell AL (2008) Enhanced binding of metabotropic glutamate receptor type 5 (mGluR5) PET tracers in the brain of parkinsonian primates. Neuroimage 42:248-251. CrossRef Medline

Sasaki T, Ito H, Kimura Y, Arakawa R, Takano H, Seki C, Kodaka F, Fujie S, Takahata K, Nogami T, Suzuki M, Fujiwara H, Takahashi H, Nakao R, Fukumura T, Varrone A, Halldin C, Nishikawa T, Suhara T (2012) Quantification of dopamine transporter in human brain using PET with 18F-FE-PE2I. J Nucl Med 53:1065-1073. CrossRef Medline

Schiefer J, Sprünken A, Puls C, LüesseHG, Milkereit A, Milkereit E, Johann V, Kosinski CM (2004) The metabotropic glutamate receptor 5 antagonist MPEP and the mGluR2 agonist LY379268 modify disease progression in a transgenic mouse model of Huntington's disease. Brain Res 1019:246254. CrossRef Medline

Schou M, Steiger C, Varrone A, Guilloteau D, Halldin C (2009) Synthesis, radiolabeling and preliminary in vivo evaluation of $\left[{ }^{18} \mathrm{~F}\right] \mathrm{FE}-\mathrm{PE} 2 \mathrm{I}$, a new probe for the dopamine transporter. Bioorg Med Chem Lett 19:48434845. CrossRef Medline

Simonyi A, Ngomba RT, Storto M, Catania MV, Miller LA, Youngs B, DiGiorgi-Gerevini V, Nicoletti F, Sun GY (2005) Expression of groups I and II metabotropic glutamate receptors in the rat brain during aging. Brain Res 1043:95-106. CrossRef Medline

Suzuki M, Ito H, Kodaka F, Takano H, Kimura Y, Fujiwara H, Sasaki T, Takahata K, Nogami T, Nagashima T, Nengaki N, Kawamura K, Zhang
MR, Varrone A, Halldin C, Okubo Y, Suhara T (2014) Reproducibility of PET measurement for presynaptic dopaminergic functions using L-[beta- $\left.{ }^{11} \mathrm{C}\right]$ DOPA and $\left[{ }^{18} \mathrm{~F}\right] \mathrm{FE}-\mathrm{PE} 2 \mathrm{I}$ in humans. Nucl Med Commun 35:231-237. CrossRef Medline

Tang FR, Chen PM, Tang YC, Tsai MC, Lee WL (2007) Two-methyl-6phenylethynyl-pyridine (MPEP), a metabotropic glutamate receptor 5 antagonist, with low doses of MK801 and diazepam: a novel approach for controlling status epilepticus. Neuropharmacology 53:821-831. CrossRef Medline

Testa CM, Standaert DG, Young AB, Penney JB Jr (1994) Metabotropic glutamate receptor mRNA expression in the basal ganglia of the rat. J Neurosci 14:3005-3018. Medline

Ulus IH, Wurtman RJ (1997) Metabotropic glutamate receptor agonists increase release of soluble amyloid precursor protein derivatives from rat brain cortical and hippocampal slices. J Pharmacol Exp Ther 281: 149-154. Medline

Vernon AC, Zbarsky V, Datla KP, Croucher MJ, Dexter DT (2007) Subtype selective antagonism of substantia nigra pars compacta Group I metabotropic glutamate receptors protects the nigrostriatal system against 6-hydroxydopamine toxicity in vivo. J Neurochem 103:1075-1091. CrossRef Medline

Vernon AC, Croucher MJ, Dexter DT (2008) Additive neuroprotection by metabotropic glutamate receptor subtype-selective ligands in a rat Parkinson's model. Neuroreport 19:475-478. CrossRef Medline

Wyckhuys T, Verhaeghe J, Wyffels L, Langlois X, Schmidt M, Stroobants S, Staelens S (2013) N-acetylcysteine- and MK-801-induced changes in glutamate levels do not affect in vivo binding of metabotropic glutamate 5 receptor radioligand ${ }^{11} \mathrm{C}-\mathrm{ABP} 688$ in rat brain. J Nucl Med 54:1954-1961. CrossRef Medline

Yamasaki T, Fujinaga M, Yui J, Ikoma Y, Hatori A, Xie L, Wakizaka $\mathrm{H}$, Kumata K, Nengaki N, Kawamura K, Zhang MR (2014) Noninvasive quantification of metabotropic glutamate receptor type 1 with $\left[{ }^{11}\right.$ C]ITDM: a small-animal PET study. J Cereb Blood Flow Metab 34: 606-612. CrossRef Medline

Yui J, Hatori A, Kawamura K, Yanamoto K, Yamasaki T, Ogawa M, Yoshida Y, Kumata K, Fujinaga M, Nengaki N, Fukumura T, Suzuki K, Zhang MR (2011) Visualization of early infarction in rat brain after ischemia using a translocator protein $(18 \mathrm{kDa})$ PET ligand $\left[{ }^{11} \mathrm{C}\right] \mathrm{DAC}$ with ultra-high specific activity. Neuroimage 54:123-130. CrossRef Medline 